Supporting Information for

\title{
Microbiome for the Electrosynthesis of Chemicals from Carbon Dioxide
}

Edward V. LaBelle (Harvard University), Christopher W. Marshall (Marquette University), and

\author{
Harold D. May (Medical University of South Carolina) \\ Corresponding author \\ Harold D. May, Professor \\ Hollings Marine Laboratory, H212-D \\ Department of Microbiology \& Immunology \\ Medical University of South Carolina \\ 331 Fort Johnson Road
}

Charleston, SC 29412-9112

Ph. 843-876-2404

$\underline{\text { mayh@musc.edu }}$

\section{Cultivation of Cutaneotrichosporon oleaginosum strain D}

Cutaneotrichosporon oleaginosum strain D (ATCC 20509) was originally revived from frozen stock in YPD medium containing $10 \mathrm{~g} / \mathrm{L}$ yeast extract, $20 \mathrm{~g} / \mathrm{L}$ peptone, and $20 \mathrm{~g} / \mathrm{L}$ dextrose. Following this, it was then routinely grown on the phosphate-based medium with $50 \mathrm{mM} \mathrm{NaCl}$ described in LaBelle 2014 and LaBelle 2017. Additionally, this medium was amended with 3 $\mathrm{g} / \mathrm{L}\left(\mathrm{NH}_{4}\right)_{2}\left(\mathrm{SO}_{4}\right), 0.1 \mathrm{~g} / \mathrm{L}$ yeast extract, and $5 \mathrm{~g} / \mathrm{L}$ acetic acid, and brought to a $\mathrm{pH}$ of 7 with KOH. $50 \mathrm{~mL}$ cultures were maintained in $300 \mathrm{~mL}$ Nephelo flasks at $30^{\circ} \mathrm{C}$ and shaking at 180 RPM. For the experiment with real microbial electrosynthesis effluent, the effluent was brought up to $5 \mathrm{~g} / \mathrm{L}$ with acetic acid, and to $\mathrm{pH}=7$ with $\mathrm{KOH}$, amended with $3 \mathrm{~g} / \mathrm{L}\left(\mathrm{NH}_{4}\right)_{2}\left(\mathrm{SO}_{4}\right)$ and 0.1 
$\mathrm{g} / \mathrm{L}$ yeast extract. The flasks were inoculated with a $10 \% \mathrm{v} / \mathrm{v}$ culture that had been transferred away from YPD medium over 25 times. Cell dry weight was calculated using a regression curve calibrated from optical density measured at $600 \mathrm{~nm}$ and $50 \mathrm{~mL}$ cell cultures that were centrifuged $(10,000 \mathrm{x} \mathrm{g})$, washed with deionized water, and dried overnight to constant weight at $105^{\circ} \mathrm{C}$ on aluminum cups $\left(\mathrm{g} / \mathrm{L}_{\mathrm{cdw}}=0.5637 * \mathrm{OD} 600, \mathrm{R}^{2}=0.9986\right)$.

\section{References}

LaBelle, Edward V, C W Marshall, Jack A Gilbert, and Harold D. May. 2014. "Influence of Acidic pH on Hydrogen and Acetate Production by an Electrosynthetic Microbiome." PLoS ONE 9 (10): 1-10. doi:10.1371/journal.pone.0109935.

LaBelle, Edward V, and Harold D. May. 2017. "Energy Efficiency and Productivity Enhancement of Microbial Electrosynthesis of Acetate." Frontiers in Microbiology 8 (May): 2059. doi:10.1021/acs.est.6b01601. 